\title{
LEGALITAS PENGUASAAN HAK ASUH ANAK DIBAWAH UMUR (HADHANAH) KEPADA BAPAK PASCA PERCERAIAN
}

\author{
Irfan Islami \\ Aini Sahara \\ Fakultas Hukum Universitas YARSI \\ Email: irfanislami@yahoo.com
}

\begin{abstract}
ABSTRAK
Salah satu akibat dari perceraian adalah penguasaan hak asuh anak kepada salah satu pasangan yang berpisah, yaitu baik kepada ibu (mantan isteri) atau kepada bapak (mantan suami). Tidak ada Undang-Undang yang mengatur secara tegas dan jelas mengenai kewajiban hak asuh anak diberikan kepada ibu kandung atau bapak kandung pasca terjadinya perceraian, satu-satunya aturan yang mengatur hal demikian terdapat pada Kompilasi Hukum Islam (KHI) Pasal 105 dimana disebutkan bahwa penguasaan Hak Asuh Anak bagi anak dibawah umur 12 tahun diberikan kepada ibu kandung. Namun terkadang dalam kasus perceraian tidak sedikit sengketa penguasaan hak asuh anak dibawah umur diberikan kepada bapak kandung. Penelitian ini dilakukan secara normatif dengan menganalisis beberapa kasus yang ada mengenai legalitas penguasaaan hak asuh anak di bawah umur oleh bapak atau mantan suami pasca perceraian ditinjau dari hukum positif yang berlaku di Indonesia.
\end{abstract}

Kata Kunci : Perkawinan, Perceraian, Hak Asuh Anak, Hadhanah, Bapak. 


\section{PENDAHULUAN}

Perkawinan merupakan suatu peristiwa penting bagi manusia, dimana manusia sebagai makhluk sosial tidak dapat hidup sendiri dalam memenuhi kebutuhan hidupnya, manusia dalam fitrahnya diciptakan dengan pasangan hidupnya masing-masing. Dalam peristiwa perkawinan diperlukan norma hukum dan tata tertib yang mengaturnya. Penerapan norma hukum dalam peristiwa perkawinan terutama diperlukan dalam rangka mengatur hak, kewajiban, dan tanggung jawab masing-masing anggota keluarga, guna membentuk rumah tangga yang bahagia, kekal dan sejahtera.

Setiap pasangan suami istri yang sudah menikah pasti berkeinginan untuk memiliki keturunan, yang secara fitrahnya anak-anak keturunan mereka tersebut merupakan amanah dari Allah SWT. Bagi setiap orang tua anak-anak keturunan mereka tersebut diharapkan kelak dapat menjadi anak-anak yang bermanfaat dan membanggakan untuk agama, nusa dan bangsa, serta dapat mengangkat derajat dan martabat kedua orantua kelak apabila anak-anak tersebut menjadi dewasa.

Fakta kehidupan menunjukkan bahwa tidak sedikit perkawinan yang dibangun dengan susah payah pada akhirnya bubar karena kemelut rumah tangga yang menghantamnya. Ikatan perkawinan yang dibangun dalam mahligai cinta dan kasih sayang dapat terputus karena tidak adanya kecocokan antara suami dan isteri seiring berjalannya waktu. Putusnya perkawinan akibat perceraian dapat terjadi karena kehendak suami atau istri atau kehendak keduanya, hal ini dilatarbelakangi oleh banyak faktor, misalkan tidak terpenuhinya hak-hak dan kewajiban-kewajiban sebagai suami atau istri, pergaulan antara suami dan istri yang tidak saling menghormati, tidak saling menjaga rahasia masing-masing, kehendak rumah tangga yang tidak aman dan tenteram, serta saling terjadi silang sengketa atau pertentangan pendapat yang sangat prinsip. ${ }^{1}$

Walaupun perceraian urusan pribadi, baik itu atas kehendak satu di antara dua pihak yang seharusnya tidak perlu campur tangan pihak ketiga (dalam hal ini pemerintah), tetapi demi menghindari tindakan sewenang, terutama dari pihak suami (karena pada umumnya pihak yang superior dalam keluarga adalah suami)

\footnotetext{
${ }^{1}$ Muhammad Syarifuddin, Hukum Perceraian, (Jakarta:Sinar Grafika,2014), hlm: 6.
} 
dan juga untuk kepastian hukum, maka perceraian harus melalui saluran lembaga peradilan. $^{2}$

Keabsahan legalitas perceraian hanya didapatkan apabila pasangan suami dan isteri mengajukan gugatan cerai atau permohonan cerai di depan sidang pengadilan. Bagi WNI yang beragama Islam dapat mengajukan perkara perceraian di Pengadilan Agama, sedangkan bagi WNI yang tidak beragama Islam dapat mengajukan perkara perceraian di Pengadilan Negeri. Walaupun pada dasarnya hukum Islam tidak mengharuskan perceraian dilakukan di depan sidang pengadilan, namun karena ketentuan ini lebih banyak mendatangkan kebaikan bagi kedua belah pihak pada khususnya, dan bagi warga negara Indonesia yang beragama Islam wajib mengikuti ketentuan ini. Selain itu, sesuai dengan asas dalam hukum positif Indonesia yang menyatakan bahwa peraturan itu berlaku bagi seluruh warga Negara, kecuali peraturan menentukan lain. Sedangkan dalam Undang-Undang Perkawinan tidak menyebutkan ketentuan lain menyangkut masalah perceraian.

Salah satu akibat dari putusnya perkawinan karena perceraian adalah timbulnya sengketa perebutan hak asuh anak antara suami dan isteri. Ikatan yang terjalin antara suami dan isteri dapat terputus karena adanya perceraian, namun ikatan anak dengan ibu dan bapak kandungnya tidak akan terputus sampai kapan pun. Oleh karena itu, antara bapak dan ibu sama-sama memiliki hak dalam pengasuhan anak khususnya anak di bawah umur atau di bawah 12 tahun. Setiap orang tua yang bercerai pasti masing-masing dari mereka menginginkan buah hatinya ada dalam penguasaannya, dimana akan timbul perbedaan keinginan dan menimbulkan berbagai masalah hukum dalam pengasuhan anak. Masalah-masalah tersebut antara lain, siapa yang harus memelihara anak-anak mereka? hak-hak apa saja yang harus diberikan oleh orang tua kepada anak-anaknya? Majelis Hakim wajib memeriksa dan mengadili setiap bagian dalam gugatan para pihak, termasuk juga tuntutan hak penguasaan anak. ${ }^{3}$

2 Wahyu Ernaningsih dan Putu Samawati, Hukum Perkawinan Indonesia,(Palembang: PT.Rambang Palembang, 2006), hlm:110-111

${ }^{3}$ Abdul Manan, Penerapan Hukum Acara Perdata di Lingkungan Peradilan Agama. Cetakan Ke-6. Jakarta : Kencana. 2012hlm :424 
Di dalam penguasaan hak asuh anak, sifat seorang pengasuh sangatlah berpengaruh terhadap tumbuh kembangnya anak, karena si anak akan mencontohi siapa orang yang terdekatnya yang kesehariannya selalu bersamanya. Bagaimana pola pengasuhan anak juga dapat membentuk karakter pribadi seorang anak, apakah dengan kasih saying atau dengan kekerasan. Anak yang mendapat perhatian lebih dari orangtua yang mengasuhnya akan berbeda karakternya dengan anak yang kurang mendapatkan kasih sayang dan perhatian. Hal-hal inilah yang dapat menjadi pertimbangan majlis hakim dalam memutuskan perkara perebutan hak asuh anak antara kedua orang tua.

Di antara Ibu dan Bapak, Ibu lebih memiliki kelembutan, sehingga dapat memberikan kasih sayang dan perhatian lebih terhadap anaknya khususnya yang masih di bawah umur, karena ibu adalah sekolah pertama bagi anak-anaknya ( $\mathrm{Al}$ Ummu Madrasatun) dan ibu juga yang memiliki sifat lebih pandai, lebih sabar, dan lebih cinta kepada anak-anaknya. Namun dalam kenyataan hidup, tidak jarang beberapa kasus perceraian yang memperebutkan hak asuh anak di bawah umur dimenangkan oleh pihak Bapak. Sudah banyak putusan pengadilan yang menjatuhkan hak asuh anak dibawah umur (hadhanah) yang bukan kepada ibunya melainkan kepada bapaknya.

Di dalam peraturan perundang-undangan Indonesia tidak ada aturan yang jelas dan tegas yang menyebutkan bahwa penguasaan anak di bawah umur setelah perceraian ada pada Ibu atau pada Bapak, satu-satunya aturan yang mengatur hal demikian ada pada Kompilasi Hukum Islam (KHI) yang dikeluarkan melalui Instruksi Presiden No. 1 Tahun 1991 tentang Penyebarluasan Kompilasi Hukum Islam. Dari sinilah yang melatarbelakangi penulis untuk mengkaji dan menganalisis secara yuridis terhadap penguasaan hak asuh anak di bawah umur (hadhanah) bagi bapak atau suami pasca perceraian. 


\section{PEMBAHASAN}

\section{Pengertian dan Dasar Hukum Hak Asuh Anak (Hadhanah)}

Pemeliharaan anak dalam bahasa Arab disebut dengan istilah "hadhanah". Hadhanah menurut bahasa berarti "meletakkan sesuatu dekat tulang rusuk atau di pangkuan", karena ibu waktu menyusukan anaknya meletakkan anak itu di pangkuannya, seakan-akan ibu di saat itu melindungi dan memelihara anaknya, sehingga "hadhanah" dijadikan istilah yang maksudnya: "pendidikan dan pemeliharaan anak sejak dari lahir sampai sanggup berdiri sendiri mengurus dirinya yang dilakukan oleh kerabat anak itu". ${ }^{4}$ Menurut Sayyid Sabiq Hadhanah adalah melakukan pemeliharaan anak-anak yang masih kecil baik laki-laki atau perempuan atau yang sudah besar tetapi belum tamyiz, tanpa perintah dari padanya, menyediakan sesuatu yang menjadikan kebaikannya, menjaganya dari suatu yang merusak jasmani, rohani, dam akalnya agar mampu berdiri sendiri dalam menghadapi hidup dan dapat memikul tanggung jawab apabila ia sudah dewasa. $^{5}$

Pemeliharaan anak juga mengandung arti sebuah tanggung jawab orangtua untuk mengawasi, memberi pelayanan yang semestinya serta mencukupi kebutuhan hidup dari seorang anak oleh orangtua. Selanjutnya tanggung jawab pemeliharaan berupa pengawasan dan pelayanan serta pencukupan nafkah anak tersebut bersifat kontinue sampai anak tersebut mencapai batas umur yang legal sebagai orang dewasa yang telah mampu berdiri sendiri. ${ }^{6}$

Hadhanah dalam hukum perdata biasa disebut dengan istilah pengasuhan atau perwalian. Hak pengasuhan atau perwalian merupakan hak seorang anak dari orang tua dan juga merupakan kewajiban orang tua terhadap anak. Pasal 45 ayat (1) dan ayat (2) Undang-Undang Perkawinan memuat ketentuan imperatif bahwa kedua orang tua wajib memelihara dan mendidik anak-anak mereka sebaikbaiknya. Kewajiban tersebut berlaku sampai anak itu kawin atau dapat berdiri sendiri.

\footnotetext{
${ }^{4}$ Zakiah Darajat, Ilmu Fiqh, (Yogyakarta: Dana Bhakti Wakaf, 1995), hlm :157

${ }^{5}$ Ibid.,hlm: 425

${ }^{6}$ M.Yahya Harahap, Hukum Perkawinan Nasional, (Medan: Zahir Trading, 1975), hlm: 204
} 


\section{Pihak Yang Berhak Melakukan Hadhanah}

Seorang anak pada permulaan hidupnya sampai pada umur tertentu memerlukan orang lain untuk membantunya dalam kehidupannya, seperti makan, pakaian, membersihkan diri, bahkan sampai kepada pengaturan bangun dan tidur. Karena itu, orang yang menjaganya perlu mempunyai rasa kasih sayang, kesabaran, dan mempunyai keinginan agar anak itu tumbuh menjadi anak baik (shaleh) di kemudian hari. Di samping itu, harus mempunyai waktu yang cukup pula untuk melakukan tugas itu. Untuk itu dapat disimpulkan bahwa pihak yang memiliki syarat-syarat tersebut adalah wanita.

Menurut Pasal 105 huruf (a) Kompilasi Hukum Islam, disebutkan bahwa hak asuh anak yang belum mumayyiz (dibawah umur 12 tahun) merupakan hak dari ibunya dan Pasal 156 huruf (a) Kompilasi Hukum Islam juga menjelaskan bahwa hak asuh anak yang masih di bawah umur 12 tahun adalah hak dari pada ibu kandungnya, dan posisi ibu kandung terebut dapat digantikan apabila ibu tersebut telah meninggal dunia, dalam Pasal ini disebutkan posisi ibu dapat digantikan oleh ayah apabila si ibu telah meninggal dunia dan perempuan garis keatas dari ibu (nenek atau tantenya) juga sudah tidak ada.

Kompilasi Hukum Islam menyatakan hak hadhanah yang utama jatuh ke tangan ibu memiliki pertimbangan bahwa ibu yang memiliki ikatan batin yang lebih kuat kepada anak, ibu yang mempunya rasa kasih sayang yang lebih di bandingkan bapak, dan ibu juga yang lebih memiliki waktu lebih banyak untuk mengasuh dan merawat anak.

Seiring dengan perkembangan zaman, sekarang tidak jarang para ibu yang memiliki kesibukan kerja di luar rumah yang melebihi kesibukan si ayah, sehingga perhatian, kasih sayang dan waktu yang seharusnya didapatkan anak dari ibunya, malah berbanding terbalik, karena kesibukan ibunya anak kehilangan semua itu dari ibunya. Beranjak dari hal tersebut, Undang-Undang perlindungan anak dan Undang-Undang Perkawinan menjelaskan bahwa siapapun yang akan mendapatkan hak asuh anak (hadhanah) baik ibu maupun bapak, harus dilihat faktor dari kepentingan anak. Jadi hak hadhanah dapat diberikan kepada ibu ataupun bapak dengan pertimbangan lebih dominan kepada ibu ataukah bapak untuk kepentingan si anak tersebut. 


\section{Regulasi Yang Mengatur Hak Asuh Anak Pasca Perceraian}

Pengasuhan anak atau hadhanah (dalam istilah Islam) adalah kewajiban orang tua untuk memelihara dan mendidik anak mereka dengan sebaik-baiknya. Pemeliharaan ini mencakup masalah ekonomi, pendidikan dan segala sesuatu yang menjadi kebutuhan pokok si anak. ${ }^{7}$ Ditinjau dari segi kebutuhan anak, terutama untuk anak-anak yang masih kecil dan belum mandiri, Hadhanah adalah suatu perbuatan yang wajib dilaksanakan oleh orang tuanya, karena tanpa Hadhanah akan mengakibatkan anak menjadi terlantar dan tersia-sia hidupnya. Undang-Undang Perkawinan No. 1 Tahun 1974 tidak mengatur secara khusus tentang pengasuhan anak secara luas dan rinci bahkan dalam Peraturan Pelaksanaannya sekalipun dalam PP nomor 9 tahun 1975 juga tidak mengaturnya. Setelah diberlakukannya Undang-Undang Nomor 7 tahun 1989 tentang Peradilan Agama dan Inpres nomor 1 tahun 1991 tentang penyebarluasan Kompilasi Hukum Islam, barulah ada aturan yang mengatur tentang penguasaan hak asuh anak bagi anak di bawah umur yaitu masalah hadhanah.

Dalam Undang-Undang Perkawinan Pasal 42 sampai Pasal 54 dijelaskan bahwa orang tua wajib memelihara dan mendidik anak-anaknya yang belum mencapai umur 18 tahun dengan cara yang baik sampai anak itu kawin atau dapat berdiri sendiri. Kekuasaan orang tua juga meliputi untuk mewakili anak tersebut mengenai segala perbuatan hukum si anak di dalam dan di luar pengadilan.

Pasal 45 menyatakan:

1) Kedua orangtua wajib memelihara dan mendidik anak-anak mereka sebaik-baiknya

2) Kewajiban orangtua yang dimaksud dalam ayat (1) pasal ini berlaku sampai anak itu kawin atau dapat berdiri sendiri, kewajiban mana berlaku meskipun perkawinan antara kedua orangtua putus.

Pasal 46 menyatakan:

1) Anak wajib menghormati orangtua dan menaati kehendak mereka yang baik

\footnotetext{
${ }^{7}$ Amir Nuruddin, Hukum Perdata Islam di Indonesia, (Jakarta : Kencana, 2004), hlm : 293
} 
2) Jika anak telah dewasa, ia wajib memelihara menurut kemampuannya, orangtua dan keluarga dalam garis lurus ke atas, bila mereka itu memerlukan bantuannya.

Pasal 47 menyatakan:

1) Anak yang belum mencapai umur 18 (delapan belas) tahun atau belum pernah melangsungkan perkawinan ada di bawah kekuasaan otangtuanya selama mereka tidak dicabut kekuasaannya.

2) Orangtua mewakili anak tersebut mengenai segala perbuatan hukum di dalam dan di luar Pengadilan.

Pasal 48 menyatakan:

"Orangtua tidak diperbolehkan memindahkan hak atau menggadaikan barang-barang tetap yang dimiliki anaknya yang belum berumur 18 (delapan belas) tahun atau belum pernah melangsungkan perkawinan, kecuali apabila ada kepentingan anak itu menghendakinya.”

Pasal 49 menyatakan:

1) Salah seorang atau kedua orangtua dapat dicabut kekuasaannya terhadap seorang anak atau lebih untuk waktu yang tertentu atas permintaan orangtua yang lain, keluarga anak dalam garis lurus ke atas dan saudara kandung yang telah dewasa atau pejabat yang berwenang dengan keputusan Pengadilan dalam hal-hal:

a. Ia sangat melalaikan kewajibannyaterhadap anaknya.

b. Ia berkelakuan buruk sekali

2) Meskipun orangtua dicabut kekuasaannya, mereka masih tetap berkewajiban untuk memberi biaya pemeliharaan kepada anak tersebut.

Satu-satunya aturan yang menyatakan secara tegas dan jelas mengenai pelimpahan hak asuh anak pasca perceraian terdapat di dalam Kompilasi Hukum Islam $(\mathrm{KHI})^{8}$. KHI di dalam pasal-pasalnya menggunakan istilah Pemeliharaan

${ }^{8}$ Kompilasi Hukum Islam (KHI) adalah peraturan yang dikeluarkan melalui Instruksi Presiden No. 1 Tahun 1991 Tentang Penyebarluasan Kompilasi Hukum Islam dan bukan merupakan peraturan perundang-undangan yang setara dengan Undang-Undang di Indonesia. Meskipun hanya dituangkan dalam bentuk Inpres, namun masih tetap mempunyai kedudukan yang cukup kuat dan mantap untuk dijadikan sebagai pedoman, landasan dan pegangan bagi para hakim dalam memeriksa dan memutuskan perkara yang menjadi wewenang Peradilan Agama. Posisi KHI dalam sistem Hukum Nasional, dapat dijelaskan sbb : 
anak dan menjelaskan pengasuhan material dan nonmaterial di dalam Bab XIV Pasal 98 sampai dengan Pasal 106 sebagai berikut:

Pasal 98 menyatakan:

1) Batas usia anak yang mampu berdiri sendiri atau dewasa adalah 21 (dua puluh satu) tahun, sepanjang anak tersebut tidak bercacat secara fisik maupun mental atau belum pernah melangsungkan perkawinan.

1) Orangtuanya mewakili anak tersebut mengenai segala perbuatan hukum di dalam dan di luar Pengadilan.

2) Pengadilan Agaman dapat menunjuk salah seorang kerabat terdekat yang mampu menunaikan kewajiban tersebut apabila kedua orangtuanya tidak mampu.

Pasal yang secara eksplisit mengatur masalah kewajiban pemeliharaan anak jika terjadi perceraian hanya terdapat dalam Pasal 105 KHI yang berisi: "Dalam hal terjadinya perceraian:

1) pemeliharaan anak yang belum mumayyiz atau belum berumur 12 tahun adalah hak ibunya;

2) pemeliharaan anak yang sudah mumayyiz diserahkan kepada anak untuk memilih di antara ayah atau ibunya sebagai pemegang hak pemeliharaannya;

3) biaya pemeliharaan ditanggung oleh ayahnya."

Dalam Pasal 105 KHI ini dijelaskan bahwa hak asuh anak yang masih berusia di bawah 12 tahun adalah hak ibunya. Namun, pemeliharaan anak juga mengandung arti sebuah tanggung jawab orangtua untuk mengawasi, memberi pelayanan yang semestinya serta mencukupi kebutuhan hidup dari seorang anak oleh orang tua. Selanjutnya, tanggung jawab pemeliharaan berupa pengawasan dan pelayanan serta pencukupan nafkah anak tersebut bersifat kontinyu sampai anak tersebut mencapai batas umur yang legal sebagai orang dewasa yang telah mampu berdiri sendiri. Dan pelimpahan tanggungjawab biaya pemeliharaan anak atau nafkah anak ada pada ayahnya meskipun hak asuh anak ada pada ibunya.

1. KHI disusun dengan memperhatikan situasi dan kondisi kebutuhan hukum umat Islam, serta diberlakukan di Indonesia

2. Sebagai pegangan bagi para hakim PA dan PTA dalam arti pedoman dan sumber pengambilan hukum dalam memeriksa, mengadili, dan memutuskan perkara

3. Sebagai hukum terapan (hukum materiil) yang digunakan di lingkungan Peradilan Agama Dalam praktek penyelesaian perkara di PA dan PTA terdapat perbedaan dalam hal penggunaan KHI. Sebagian ada yang menggunakan secara eksplisit, sebagian lainnya tidak. Adapun fungsi KHI adalah untuk melengkapi, mendukung, menopang dan memberi penegasan ulang serta penjabaran lebih lanjut atas UU No.1/1974 beserta PP.No.9/1975;PP.No.28/1977 dan UU No.7 Tahun 1989, dimana penjabaran yang bernuansa dan bernafas Islam ini dapat dijadikan pedoman, landasan dan pegangan bagi pencari keadilan dan para praktisi hukum, khususnya para hakim Peradilan Agama. 
Di dalam Kompilasi Hukum Islam mengatur tentang kekuasaan orang tua terhadap anak pasca perceraian dengan kriteria umur 12 tahun, karena usia ini anak dianggap telah akil balig. Berdasarkan kriteria 12 tahun ini, maka anak yang belum memasuki usia 12 tahun akan berada dibawah kekuasaan ibunya. Setelah melewati usia 12 tahun, anak diperbolehkan menentukan pilihan sendiri, apakah ikut ibu atau ayah. Namun demikian angka 12 tahun ini bukan angka mati berdasarkan kriteria manfaat atau madharat, majelis hakim dapat menentukan keputusannya sendiri menyesuaikan keadaan dan fakta dalam persidangan.

Orang yang akan menjadi pengasuh anak disyaratkan mempunyai kafa'ah atau martabat yang sepadan dengan kedudukan si anak, mampu melaksanakan tugas sebagai pengasuh anak. Karena, dengan adanya kemampuan dan kafa'ah, maka mencakup beberapa syarat tertentu, dan apabila syarat-syarat tersebut tidak terpenuhi maka gugurlah haknya untuk mengasuh anak. ${ }^{9}$

\section{Pengasuhan Anak Di Bawah Umur Kepada Bapak Pasca Perceraian}

Pelimpahan hak asuh anak di bawah umur kepada Ibu oleh majlis hakim dipertimbangkan dari banyak faktor yang melatarbelakangi, di antaranya karena faktor psikologis, kedekakatan antara ibu dan anak sejak kandungan menjadikan mereka tak mungkin mudah untuk dipisahkan. Ibu lebih memiliki kelembutan, sehingga dapat memberikan kasih sayang dan perhatian yang lebih terhadap anaknya khususnya yang masih di bawah umur. Ibu juga merupakan sekolah pertama bagi anak-anaknya sebagaimana dalam pepatah arab mengatakan "Alummu madrasatul ula, iza a'dadtaha a'dadta sya'ban thayyibal a'raq." Yang artinya: "Ibu adalah sekolah utama, bila engkau mempersiapkannya, maka engkau telah mempersiapkan generasi terbaik". Dan ibu juga pada umumnya memiliki sifat lebih pandai, lebih sabar, dan lebih cinta kepada anak-anaknya.

Di dalam KHI Pasal 105 telah jelas mengatur bahwa hak asuh anak di bawah umur 12 tahun adalah hak ibunya. Namun pasal ini bukan berarti meniadakan atau menghapus hak bapak untuk mengasuh anak kandungnya pasca perceraian dengan isterinya. Fakta persidangan ada beberapa kasus yang telah diputuskan oleh majlis hakim memberikan hak asuh anak di bawah umur kepada bapak pasca perceraian, sebut saja beberapa contoh kasus yang terkenal dari

\footnotetext{
${ }^{9}$ H.S. Al-Hamdani, Risalah Nikah (Jakarta : Pustaka Amani, 1989), hlm:321
} 
kalangan artis Ahmad Dani, Anang Hermansyah, Ben Kasyafani, Atalarik Syah, dan masih banyak yang lainnya, yang mereka semua memenangkan kasus perebutan hak asuh anak di bawah umur pasca perceraian.

Pengasuhan anak oleh Bapak di dalam aturan positif sebagaimana tertuang dalam KHI merupakan pilihan kedua bagi majlis hakim setelah si Ibu dinilai tidak sanggup atau kurang baik untuk diberikan hak asuh anak karena pertimbangan kemaslahatan tumbuh kembangnya anak yang lebih baik untuk kedepannya. Pelimpahan hak asuh anak kepada bapak juga dijadikan alternatif pilihan setelah ibunya dinyatakan telah meninggal dunia sebagaimana tertuang dalam Pasal 156 Kompilasi Hukum Islam pada butir (c) disebutkan bahwa bapak dapat menjadi pengasuh dari anak nya apabila si ibu telah meninggal dunia dan perempuanperempuan dalam garis lurus ke atas dari ibu sudah tidak ada lagi. Pasal ini dapat menjadi acuan bahwa seorang bapak juga mempunyai hak dalam pengasuhan dan pemeliharaan anaknya meskipun hak tersebut sangatlah jauh dibanding dengan hak dari seorang ibu.

Pasal 49 ayat (1) Undang-Undang Perkawinan juga menjelaskan bahwa kekuasaan salah satu dari orang tua si anak dapat dicabut demi mengedepankan kepentingan si anak. Hal ini dapat dianalogikan bahwa seorang ibu atau bapak apabila terjadi perceraian diantara keduanya maka salah satu dari mereka yang memiliki hak hadhanah untuk anaknya (dalam hal ini seorang ibu) dapat dicopot apabila dirinya sudah tidak memiliki unsur kepentingan bagi si anak. Pasal 14 Undang-Undang No. 23 Tahun 2002 Tentang Perlindungan Anak juga menjelaskan, Setiap anak berhak untuk diasuh oleh orang tuanya sendiri, kecuali jika ada alasan dan/atau aturan hukum yang sah menunjukkan bahwa pemisahan itu adalah demi kepentingan terbaik bagi anak dan merupakan pertimbangan terakhir.

Dalam konteks globalisasi pada semua aspek kehidupan manusia, terminologi pemeliharaan anak perlu dipahami secara lebih luas dan menyeluruh. Ini dimaksudkan, agar orang tua tidak hanya memprioritaskan kewajibannya pada terpenuhinya kebutuhan materiil si anak, tetapi lebih dari itu kebutuhan mereka akan cinta dan kasih sayang, pendidikan, kesehatan, dan lain-lain turut menjadi 
faktor penentu pembentukan kepribadian anak. Kualitas komunikasi antara anak dan orang tuanya mutlak perlu mendapatkan perhatian. ${ }^{10}$

Setiap orang yang memiliki hak hadhanah hendaknya memiliki rasa kasih sayang, kesabaran, dan mempunyai keinginan agar anak itu baik (shaleh/shalehah) di kemudian hari. Selain itu harus mempunyai waktu yang cukup pula untuk melaksanakan tugas itu. Jika dilihat dalam Pasal 156 dijelaskan bahwa hak hadhanah anak yang belum mumayyiz merupakan hak ibu, dan dapat digantikan oleh ayah apabila si ibu telah meninggal dunia dan wanita-wanita dalam garis lurus ke atas dari ibu sudah tidak ada lagi. Menurut hukum Romawi yang berpengaruh banyak terhadap hukum Perancis dan melalui hukum Belanda sampai ke Indonesia dan masuk ke dalam hukum Perdata BW, dijelaskan bahwa anak-anak berada di bawah kekuasaan bapaknya.

Semula kekuasaan ini (patria potesta) tidak terbatas dan dapat dikatakan bahwa hidup dan matinya seorang anak berada dalam kekuasaan bapaknya. Lambat laun kekuasaan ini menjadi berkurang, namun tetap saja masih besar dibanding dengan kekuasaan ibunya. ${ }^{11}$ Dengan diadakannya perundang-undangan anak, maka kekuasaan bapak diubah menjadi kekuasaan orangtua (ibu dan bapak), dan dengan keputusan hakim kekuasaan orangtua dapat dibebaskan atau dipecat dari hak pengasuhan anak. ${ }^{12}$

Dalam memutus pelimpahan hak asuh anak (hadhanah) dilimpahkan kepada bapak, hakim suatu pengadilan memiliki beberapa pertimbangan hukum agar putusan yang dikeluarkanya tidak menyimpang dari peraturan perundangundangan yang berlaku di Indonesia. Namun, secara tekstual hukum positif di Indonesia tidak ada yang mengatur bagaimana hak asuh anak (hadhanah) dapat dilimpahkan kepada bapaknya. Pasal 156 kompilasi Hukum Islam menjelaskan bahwa, hadhanah sewajarnya diberikan kepada ibu dari anak tersebut dan hadhanah kepada ibu baru dapat digantikan apabila si Ibu telah meninggal dunia. Dalam pasal ini dijelaskan pula, bahwa ayah dapat menggantikan posisi ibu apabila ibu sudah meninggal dunia dan wanita-wanita dalam garis lurus atas dari ibu juga sudah tidak ada.

\footnotetext{
${ }^{10}$ Ibid, hlm: 192

11 Martiman Prodjohamidjodjo, Hukum Perkawinan Indonesia, (Jakarta: Indonesia Legal Center Publishing,2002), hlm: 65

${ }^{12}$ Amiur Nuruddin, Hukum Perdata Islam di Indonesia, (Jakarta:Kencana, 2004), hlm: 292
} 
Kompilasi Hukum Islam tidak mengatur mengenai pencabutan hak hadhanah si ibu, namun dalam hal ini dapat dipakai pengaturan mengenai pencopotan hak perwalian. Hal ini digunakan karena dalam Kitab Undang-Undang Hukum Perdata di Indonesia hak asuh, hak mendidik, mengasuh dan lain sebagainya masuk dalam kategori hak perwalian.

Sesorang dapat ditarik, diangkat, dicopot dari statusnya sebagai wali apabila dia mempunyai sifat-sifat tertentu, dalam Pasal 109 Kompilasi Hukum Islam disebutkan bahwa Pengadilan Agama dapat mencabut perwalian seseorang atau badan hukum dan memindahkannya kepada pihak lain atas permohonan kerabatnya bila wali tersebut pemabuk, penjudi, pemboros, gila dan atau melalaikan atau menyalahgunakan hak dan wewenangnya sebagai wali demi kepentingan orang yang berada di bawah perwaliannya. Kekuasaan orang tua dapat dicabut atau dialihkan apabila ada alasan-alasan yang menuntut pengalihan tersebut, sebagaimana dinyatakan dalam Pasal 49 Undang-Undang Nomor 1 tahun 1974 tentang Perkawinan: ${ }^{13}$

a. Salah seorang atau kedua orang tua dapat dicabut kekuasaannya terhadap seorang anak atau lebih untuk waktu yang tertentu atas permintaan orang tua yang lain, keluarga anak dalam garis lurus ke atas dan saudara kandung yang telah dewasa atau pejabat yang berwenang, dengan keputusan pengadilan dalam hal:

1) Ia sangat melalaikan kewajibannya terhadap anaknya.

2) Ia berkelakuan buruk sekali.

b. Meskipun orang tua dicabut kekuasaanya, mereka masih tetap berkewajiban untuk memberi biaya pemeliharaan kepada anak tersebut.

Pasal 14 Undang-Undang Perlindungan anak juga menjelaskan bahwa setiap anak berhak untuk diasuh oleh orang tuanya sendiri, kecuali jika ada alasan atau aturan hukum yang sah menunjukkan bahwa pemisahan itu adalah demi kepentingan terbaik bagi anak dan merupakan pertimbangan mutakhir. Namun demikian, setiap anak berhak atas :

a. bertemu langsung dan berhubungan pribadi secara tetap dengan kedua orang tuanya;

b. mendapatkan pengasuhan, pemeliharaan, pendidikan dan perlindungan untuk proses tumbuh kembang dari kedua orang tuanya sesuai dengan kemampuan, bakat, dan minatnya;

${ }^{13}$ Ahmad Rofiq, Hukum Perdata Islam di Indonesia, (Jakarta : Rajawali Pers, 2013), hlm: 202 
memperoleh pembiayaan hidup dari kedua orang tuanya; dan memperoleh hak anak lainnya.

Pasal 14 undang-undang perlindungan anak ini juga menjadi pertimbangan para hakim dalam memutus perkara Hadhanah, kepentingan anak menjadi dasar siapa dari salah satu orang tua yang berhak mendapatkan hak hadhanah apabila suatu ketika rumah tangga orangtua si anak putus akibat perceraian. Jadi, hak hadhanah tidak mesti diberikan kepada ibunya, melainkan dapat juga dilimpahkan kepada bapaknya.

Undang-Undang Nomor 1 tahun 1974 tentang perkawinan, didalamnya juga mengatur ketentuan terkait hadhanah, hal tersebut tercantum dalam pasal 41 huruf (a) yang menyatakan bahwa "baik ibu maupun bapak tetap berkewajiban memelihara dan mendidik anak-anaknya, semata-mata berdasarkan kepentingan anak;" jelas dalam pasal ini juga disinggung mengenai kepentingan anak, dan kepentingan anak menjadi faktor terpenting mengalahkan fakto-faktor yang lainnya.

Dari beberapa pasal yang menyatakan hak hadhanah harus memperhatikan kepentingan si anak, jika hak hadhanah yang akan diberikan kepada ibu sudah tidak ada lagi kepentingan si anak di dalamnya maka hak hadhanah tersebut dapat diberikan kepada bapaknya. Diibaratkan jika si ibu seorang pemabuk, penjudi dan tindakan-tindakan unmoral lainnya ataupun memiliki sifat temperamental, maka akan memicu kepada tindakan-tindakan kekerasan yang akan dilakukan oleh ibu kepada anaknya bahkan mungkin saja bisa membunuh anak tersebut. Dapat disimpulkan bahwa faktor-faktor yang dapat menyebabkan hak hadhanah diberikan kepada bapaknya antara lain :

1. Mengedepankan kepentingan si anak;

2. Si ibu memiliki sifat-sifat unmoral;

3. Mengacu pada kepentingan anak menurut Undang-Undang Perlindungan Anak;

4. Mengacu pada pasal 109 Kompilasi Hukum Islam tentang pencabutan perwalian;

5. Tidak terpenuhinya syarat-syarat untuk mendapatkan hak hadhanah; 
Karena undang-undang tidak menjelaskan secara jelas mengenai faktor-faktor pelimpahan hadhanah maka kelima hal tersebut secara analogi dapat dijadikan sebagai faktor-faktornya.

\section{PENUTUP}

\section{Kesimpulan}

Pelimpahan hak asuh anak di bawah umur pasca perceraian dalam UndangUndang Perkawinan No. 1 Tahun 1974 tidak diatur secara rinci dan jelas menjadi hak bapak atau hak ibu. Namun di dalam Pasal 105 Kompilasi Hukum Islam dijelaskan bahwa hak asuh anak yang masih berusia di bawah 12 tahun adalah hak ibunya. Ada beberapa peraturan perundang-undangan di Indonesia yang dapat dijadikan acuan agar hak asuh anak di bawah umur tersebut dapat dilimpahkan kepada Bapak kandungnya, di antaranya: Pasal 109 Kompilasi Hukum Islam mengenai pencabutan perwalian; Pasal 41 Undang-Undang Nomor 1 Tahun 1974 tentang Perkawinan, mengenai persamaan hak antara Ibu dan Bapak terkait hak asuh anak dengan mengedepankan kepentingan dari anak tersebut; Pasal 49 Undang-Undang Perkawinan mengenai permintaan pencabutan hak asuh anak oleh salah satu orangtua maupun keluarga dari anak tersebut; dan Pasal 14 Undang-Undang Perlindungan Anak mengenai pemisahan seorang anak dengan salah satu ataupun kedua orangtuanya demi kepentingan terbaik bagi anak dan merupakan pertimbangan mutakhir dengan tidak menghilangkan hak-hak seorang anak yang harus dipenuhi oleh orangtua. Dari beberapa pasal yang menyatakan hak hadhanah harus memperhatikan kepentingan si anak, jika hak hadhanah yang akan diberikan kepada ibu sudah tidak ada lagi kepentingan si anak di dalamnya maka hak hadhanah tersebut dapat diberikan kepada bapaknya. Diibaratkan jika si ibu seorang pemabuk, penjudi dan tindakan-tindakan unmoral lainnya ataupun memiliki sifat temperamental, maka akan memicu kepada tindakan-tindakan kekerasan yang akan dilakukan oleh ibu kepada anaknya bahkan mungkin saja bisa membunuh anak tersebut. 


\section{Saran}

Setelah mengetahui pengaturan dalam hukum positif di Indonesia mengenai hak asuh anak di bawah umur (hadhanah) masih ada hal-hal yang menimbulkan interprestasi yang luas di masyarakat sehingga kepastian hukum menjadi tidak jelas atau kurang jelas, maka Pemerintah seharusnya melakukan amandemen terhadap Kompilasi Hukum Islam yang merupakan Inpres Nomor 1 Tahun 1990 dikarenakan situasi dan kondisi masyarakat yang sudah semakin berkembang dan berubahnya tatanan pola kehidupan di masyarakat. Terutama dalam Pasal 105 Kompilasi Hukum Islam seharusnya dihapuskan saja, karena baik ibu maupun bapak memiliki hak yang setara dan sama sebagai orangtua untuk mengasuh, memelihara, dan merawat serta melindungi hak-hak anak. Dengan tidak adanya peraturan khusus mengenai hak asuhan anak kepada Bapak, seharusnya Pemerintah membuat peraturan khusus mengenai pelimpahan hak asuh anak di bawah umur (hadhanah) demi terciptanya kepastian hukum dikemudian hari. 


\section{DAFTAR PUSTAKA}

Abidin, Slamet. Fiqh Munakahat 2. Bandung : CV.Pustaka Setia. 1999.

Al-Hamdani, H.S. Risalah Nikah. Jakarta : Pustaka Amani. 1989.

Amshori, Ibnu. Perlindungan Anak Menurut Perspektif Hukum Islam. Jakarta : Komisi Perlindungan Anak Inonesia. 2007.

Bintania, Aris. Hukum Acara Peradilan Agama dalam kerangka Fiqh al-Qadha. Jakarta : Rajawali Pers. 2012.

Dahlan, Abdul Aziz. Ensiklopedi Hukum Islam. Jilid 1.

Darajat, Zakiah. Ilmu Fiqh. Yogyakarta: Dana Bhakti Wakaf. 1995.

Ernaningsih, Wahyu dan Putu Samawati. Hukum Perkawinan Indonesia. Palembang: PT.Rambang Palembang. 2006.

Ghozali, Adbul Rahman. Fiqh Munakahat. Cetakan Ke-6. Jakarta: Kencana. 2012

Kamus Besar Bahasa Indonesia, http//:ebsoft.web.id. (diakses pada 20 November 2015)

Manan ,Abdul. Penerapan Hukum Acara Perdata di Lingkungan Peradilan Agama. Cetakan Ke-6. Jakarta : Kencana. 2012.

Mustakim, Abdul. Kedudukan dan Hak-hak Anak dalam Perspektif al-Qur'an. (Artikel Jurnal Musawa, vol.4 No. 2). Juli-2006.

Nuruddin, Amir. Hukum Perdata Islam di Indonesia. Jakarta : Kencana, 2004.

Poerwadarminta, W.J.S. Kamus Umum Bahasa Indonesia. Jakarta: Balai Pustaka. 1989.

Prodjohamidjodjo, Martiman. Hukum Perkawinan Indonesia. Jakarta: Indonesia Legal Center Publishing,2002.

Ramulyo, Mohd.Idris. Hukum Perkawinan Islam. Jakarta: PT. Bumi Aksara. 2004.

Rasyid, Sulaiman. Fiqh Islam. Jakarta: Attahiriyah Jakarta. 2014

Rofiq, Ahmad. Hukum Perdata Islam Di Indonesia. Jakarata : Rajawali Pers. Edisi Revisi. Cetakan 1. 2013

Said, H.A. Fuad. Perceraian Menurut Hukum Islam. Jakarta: Pustaka Al-Husna. 1994

Sarwono, Sarlito W. Pengantar Psikologi Umum. Jakarta : Rajawali Pers. 2014. 
Soekanto, Soejono. Pengantar Penelitian Hukum. Jakarta : Universitas Indonesia (UI-Press). 2012.

Sudarsono. Hukum Perkawinan Nasional. Jakarta: PT.Rineka Cipta. 1994.

Syaifuddin, Muhammad, Sri Sutarmiyah dan Annalisa Yahanan. Hukum Perceraian. Cetakan ke-2. Jakarta : Sinar Grafika. 2013.

Thalib. Muhammad. 40 Petunjuk Menuju Perkawinan Islami. Bandung : Irsyad Baitus Salam. 1995.

Tutik, Titik Triwulan. Hukum Perdata dalam Sistem Hukum Nasional. Jakarta : Kencana. 2011.

Uwaidah, Syaikh Kamil Muhammad. Fiqh Wanita. Jakarta: E.M.Pustaka AlKautsar. 1998. 